\title{
An Investigation of Consumer Behavior in Online Trade During the Covid-19 Pandemic: A Case Study
}

\author{
Aurela BRAHOLLI* \\ European University of Tirana, Faculty of Economy, Tirana, Albania, Rr. "Xhanfizo Keko", Nr.56, Tirane, \\ Email: aurela.braholli@uet.edu.al \\ ${ }^{*}$ Corresponding Author
}

\begin{abstract}
Received: 27.11 .2021
Accepted: 25.12.2021

Published: 01.02.2022

DOI: 10.47750/QAS/23.186.07

Abstract

Online commerce in recent years has received a great development becoming a key element of all economic sectors. The era of online shopping has begun and the Covid19 pandemic caused it to gain more weight in the world economy. During the period of February-May 2020 from various studies results an abnormal behavior of consumers for purchases. Before making a decision about investment in e-commerce, it may be wise to analyze consumer behavior, their attitudes towards online shopping and also towards other social and cultural factors. The study aimed to scrutinize the consumer behavior during the pandemic and its impact on the development of e-commerce. The partcipants were composed of randomly selected 350 respondents between the ages of 16-50. The data were collected via questionnaires, Shopify reports and pandemic situation reports. In the data analysis process, linear regression analysis was conducted, and 95\% reliability level was used to validate the hypotheses. The ressults revealed that consumer behavior changed during the Covid-19 pandemic, and even divided into age groups, the $Z$ generation of age became the consumers of hand-made food products. In addition, online commerce and businesses integrated in the concrete shopify platform experienced an increase of high levels equal to the sum of the increases of 10 years of online commerce.
\end{abstract}

Keywords: Consumer behavior, Covid-19 pandemic, e-commerce, investment

\section{Introduction}

Digitalization has changed our society dramatically in recent decades. New opportunities as well as challenges have emerged for both consumers and companies. Development has been rapid and sales of goods and services through digital platforms have increased tremendously. This type of trade is called e-commerce. E-Commerce is a modern platform for doing Business, in which the purchase and sale of goods, as well as services is done through electronic channels. E-commerce has become one of the most powerful business opportunities to grow. Most companies are trying to implement e-commerce especially after January 2020 where it consists of pandemic condition. Online commerce significantly reduces transaction costs. Eliminates some fixed costs. This advantage makes companies operating on the online platform achieve a higher profit margin.

E-commerce brings convenience to customers as they do not need to leave home and only need to browse the companies' websites. This can help customers buy wider range of products and save their time. They are able to research products and compare prices between sellers. Also, online shopping often offers sales promotion or discount code, so it is more valuable to customers. Furthermore, e-commerce provides detailed product information. Even the store staff cannot provide such a detailed explanation. Customers can also review and track online order history.

The contemporary e-commerce trend recommends that companies shift the traditional business model, where the focus is on "standardized products, homogeneous market and long product life cycle", to the new business model, where it focuses on "diversified products". and adapted ". E-commerce requires the company to have the ability to satisfy the multiple needs of different customers and provide them with a wider range of products.

\subsection{Top Business Classifications in E- commerce}

E-commerce includes all the online marketing software that connects buyers and sellers. The Internet is used to process all electronic transactions. This important sector is a large area classified into:

B2B: Business to Business. One such model focuses on securing products from one business to another. While many businesses in this country are service providers but there are also software companies, office furniture and supply companies and other e-commerce business models under this title. Examples of B2B e-commerce are: ExxonMobil Corporation and Chevron Corporation, Boeing and Archer Daniel Midlands. These businesses have personalized enterprise ecommerce platforms that work directly with other businesses in a closed environment. A B2B ecommerce business usually requires more startup money.

B2C: Business-Consumer Trade. The B2C sector is what most people think of when planning to start a $\mathrm{B} 2 \mathrm{C}$ business. This sector contains $64 \%$ of the weight in e-commerce. (Anwar, 


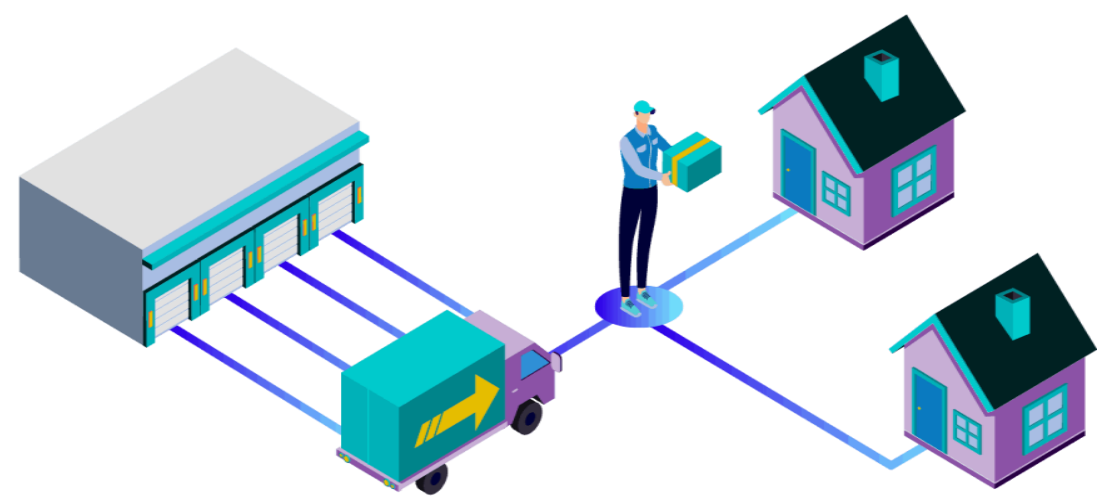

Figure 1: B2C Distribution

B2C sales are the traditional retail model, where a business sells to individuals, but the business takes place online as opposed to a physical store. The most effective companies in B2C are Amazon, AliBaba, Shopify. These companies account for $74 \%$ of B2C e-commerce coverage. (E-commerce, 2020)

C2C: Consumer-Consumer

Created by growing the e-commerce sector and increasing consumer confidence in online business, these websites allow customers to trade, buy and sell items in exchange for a small commission paid on the site. Opening a $\mathrm{C} 2 \mathrm{C}$ site requires careful planning. Despite the apparent success of platforms like eBay and Craigslist, numerous auctions and classified websites (major arenas for $\mathrm{C2C}$ ) have opened and closed quickly due to unsustainable patterns.

Trade Government-Public Administration

The models listed above are the main retail structures in the trade, but they are not the only ones. Other types include government / public administration conducting transactions with businesses or consumers. B2G (also called B2A), for businesses whose sole clients are governments or the type of public administration. An example is Synergetics Inc. in Ft. Collins, Colorado, which provides contractors and services to government agencies. C2G (also called C2A): usually individuals who pay government taxes or tuition at universities. Two sectors that are closed to entrepreneurial owners but are growing include G2B for government sales to private businesses, and $\mathrm{G} 2 \mathrm{C}$ for government sales to the general public.

\subsection{Shopify.Inc}

Shopify.Inc is a Canadian multinational e-commerce company based in Ottawa, Ontario. This company is part of the SaaS category (software as a service) and is considered the best e-commercing platform in the B2C category. Shopify offers online retailers a package of services "including payment, marketing, shipping, online business simplification. This has created a good alternative during the 2020 pandemic period to save small or large businesses from bankruptcy. Also from Many supporters of online commerce are considered a new way to "escape" from the traditional economy. The company creates the flexibility to access and run your business from anywhere with an Internet connection. multiple, including web, mobile, social media, online marketplace, manage products, inventory, payments and shipping.

The company reported that it had more than $1,000,000$ businesses in nearly 175 countries using its platform since June 2019 , with total gross merchandise volume exceeding $\$ 41.1$ billion for the 2018 calendar year and about $18 \%$ more in the calendar year 2019. According to company reports during the first 5 months of 2020 the growth of stores, sales and profits has exceeded $95 \%$ of the value of the previous year. (Taylor, 2020). In fact, Shopify lists the largest businesses like Heineken, Staples, General Mills and D-Link as clients. Another factor may help explain Shopify's growing success: It serves as an alternative for all online consumers who do not want to use the Amazon platform.

With the quarantine of the economy and business during the period February-June 2020, online trade was one of the 5 most developed sectors in the world economy, where the profits of companies in this sector exceeded $45-65 \%$ of profits during 2019 (Taylor, 2020). In this situation one of the factors to study is consumer behavior on online B2C sales and the most demanded products by consumers in the company Shopify.

\section{Literature review}

\subsection{The impact of the pandemic on e- commerce}

The global economy is going through an abnormal period of money movement, business liquidity, supply and demand for various products and services. Since the period of March 8, 2020 , the total quarantine of society and the economy has brought a great fear for a decrease in the development of the economy, for the increase of the number of bankrupt businesses, blockage of the root industries of the economy, is a global review. (Taylor, 2020). Recession is an economic term that implies a decline in a country's economic activity, a contraction of the business cycle reflected in real GDP, real income, employment, industrial production and wholesale-retail. This stage occurs when there is a large decline in spending in an economy (Webster, 2020). An element of the review such as sales-purchases have been greatly affected by the pandemic. For a period of 3 months all physical stores in the US, Europe and Asia closed and the most affected industry was the fashion, aviation, and international trade industries. Small and medium business took a strong hit by creating stock of products, profit went towards zero as demand went to zero. So supply-demand was shaken a lot. According to the New York Times over 1.5 million businesses closed for the March-May period and losses exceeded $\$ 800$ billion in the US, where the restaurant and bar industry alone suffered $\$ 450$ billion in losses (Keller, 2020; Keller, 2020).

As news of COVID-19 spread and as a pandemic was officially declared by the World Health Organization, people responded by settling in their homes. They bought medical products such as hand sanitizer, masks and essential household 
items such as toilet paper and accompanying products. People react to crises in different ways. When faced with an insecure, dangerous situation over which we have no control, we tend to try everything so that we can feel as if we have everything under control (Meyer, 2020). Paul Marsden, a consumer behavior psychologist at the University of the Arts London, was quoted by CNBC as saying: "Putting panic can be understood as playing with our three basic needs of psychology." These needs are autonomy (or the need to feel in control of his actions), connection (the need to feel that we are doing something for the benefit of our families) and competence (the need to feel like smart buyers making the choice of proper) (Meyer, 2020). While the data show that shopping behaviors are changing based on generational changes, we are also seeing gender-based changes. Survey data show that women are more likely to worry about the effects of COVID-19. It also shows that men are more likely to influence their buying behaviors. One-third of men, compared to $25 \%$ of women, reported that the pandemic has affected how much they spend on products. Moreover, $36 \%$ of men, compared to $28 \%$ of women, reported that they influence their spending on experiences (travel, restaurants, entertainment, etc.) (Meyer, 2020).

Men were the ones who did the most shopping online and avoided experiences inside stores. This includes taking advantage of options that limit in-store interactions such as BOPIS being part of Shopify (online shopping, in-store purchases), back-end acquisitions and subscription services. Retailing from the internet has increased significantly and is becoming the main focus of consumer spending, this also applies to services. From the survey created by Smart Company, the reasons for use that had significantly increased the desire to shop online during the pandemic were:

- Easier to compare and find the lowest price.

- Ease of shopping anytime anywhere.
- $\quad$ Free shipping and return policies.

- Avoiding stressful crowds and parking.

The question arises who are the real winners and what role does Online Trade play, specifically in the company Shopify.

As COV19 hit China, the chain effect was felt immediately in the west where the activity of Chinese factories decreased by $12.5 \%$ of their production in February 2020 compared to the same period in 2019, and also investment in fixed assets decreased by $25 \%$. The epicenter of the virus quickly spread to Europe and then to the US and the latter was hit hard by the collapse of stock markets. Goldman Sachs analysts in an interview indicated that they were expecting a contraction in US gross domestic product at an annual rate of $5 \%$ in the second quarter of 2020 and that it would be the biggest decline since the end of 2008. But, on the other hand, unlike the 2008 crisis, this crisis is being affected by the pandemic and is not a sectoral crisis, but a radical economic crisis that affects all economic sectors. Travel bans, quarantines and fears are variables that affected the economy and airlines around the world where they managed to lay off $85 \%$ of the workforce. Governments tried to subsidize the companies that were most at risk, but the limited cash flow exhausted the opportunities to seek credit. Alibaba CEO has already called the pandemic a black swan. This is because, despite the large level of saturation of the Chinese market with various e-commerce formats, only in the last quarter of 2019 only Alibaba recorded 38\% growth compared to the same period last year. This allowed a turnover of $\$ 23$ billion to be achieved. The situation is similar in the US. Amazon is already planning to hire an additional 100,000 employees in its logistics centers and increase salaries for all employees by $\$ 2$ per hour. This step is accompanied by a huge increase in online sales.

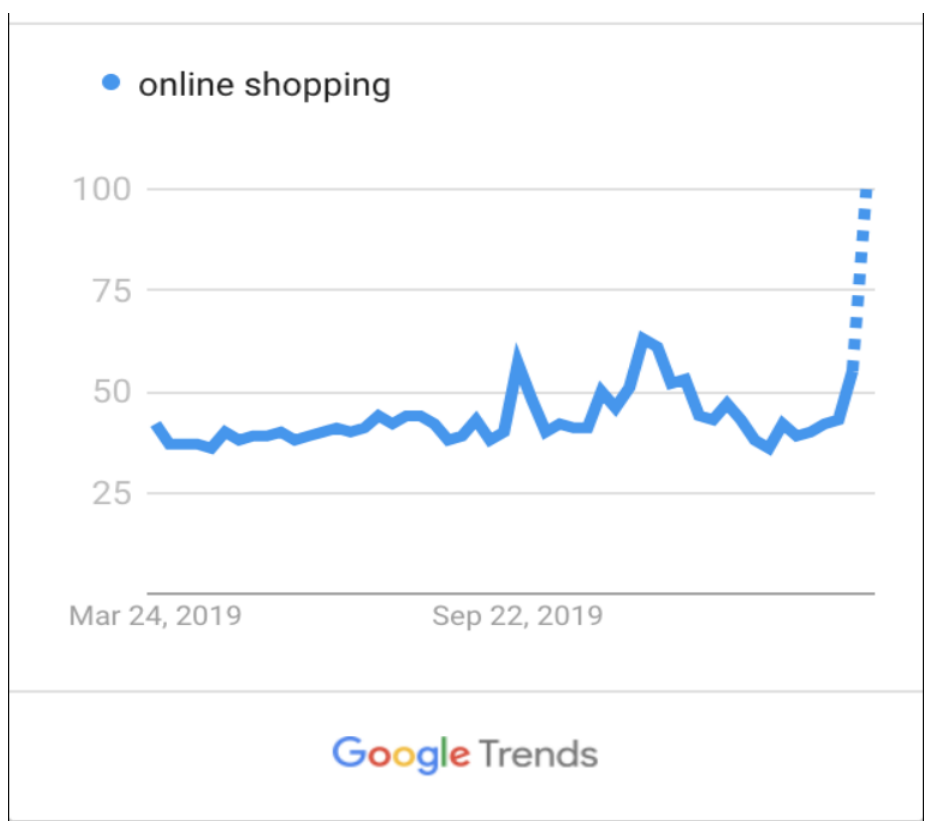

Graph 1: Trend of searching on google- online shopping

This fragment is similar to the crisis caused by the SARS epidemic in 2003 in the state of China where e-commerce led by the Alibaba platform reached the highest levels in sales history. However, on the other hand, the economy has problems, it is sick. Without the coordinated efforts of policymakers, the fiscal and monetary systems, the economy could fall into a critical state. This moment has a direct impact on the workforce, as everything will be replaced by the technological system (online commerce), it also affects public welfare and health (Taylor, 2020).

\subsection{COVID-19 and Consumer Behavior}

The e-commerce business has been placed in significant 
constraints due to pressure from the COVID-19 pandemic. Ecommerce is identified as a variable dependent on the increase or decrease in demand on the online platform. This is influenced by the spread of COVID-19 and also by the client's attitude towards this global issue. Online business is mainly dependent on these two factors that can affect its overall market demand. For this particular reason, customers have shifted towards ecommerce approaches. This is considered the only means by which the population may be able to survive this pandemic situation. The growing audience is trying to take advantage of digital facilities for food products. The mobile app tracking unit known as Apptopia has signaled that the daily downloads of popular gaming apps like Walmart Grocery, Instacart, and Shopify have reached significantly higher levels of online sales and usage since the end of February. . (Taylor, 2020)
Changed customer behavior is also considered as an independent variable. By buying wholesale through online stores, people are now changing their shopping habits and now they are more careful about what they buy, when and how. As for the significant impact of this pandemic, customers will take the necessary precautions and are more likely to act accordingly. Just as consumer behavior is being affected, in the same way, the effect of the COVID-19 explosion on e-commerce is affecting different geographies. For this particular reason, the customer must depend primarily on the e-commerce platform to meet the essential needs required for their core products. According to Morning Consult, consumers in the UK, Japan and Germany were experiencing diminished confidence when shopping for groceries, while in the US, consumer confidence was close to a high level.

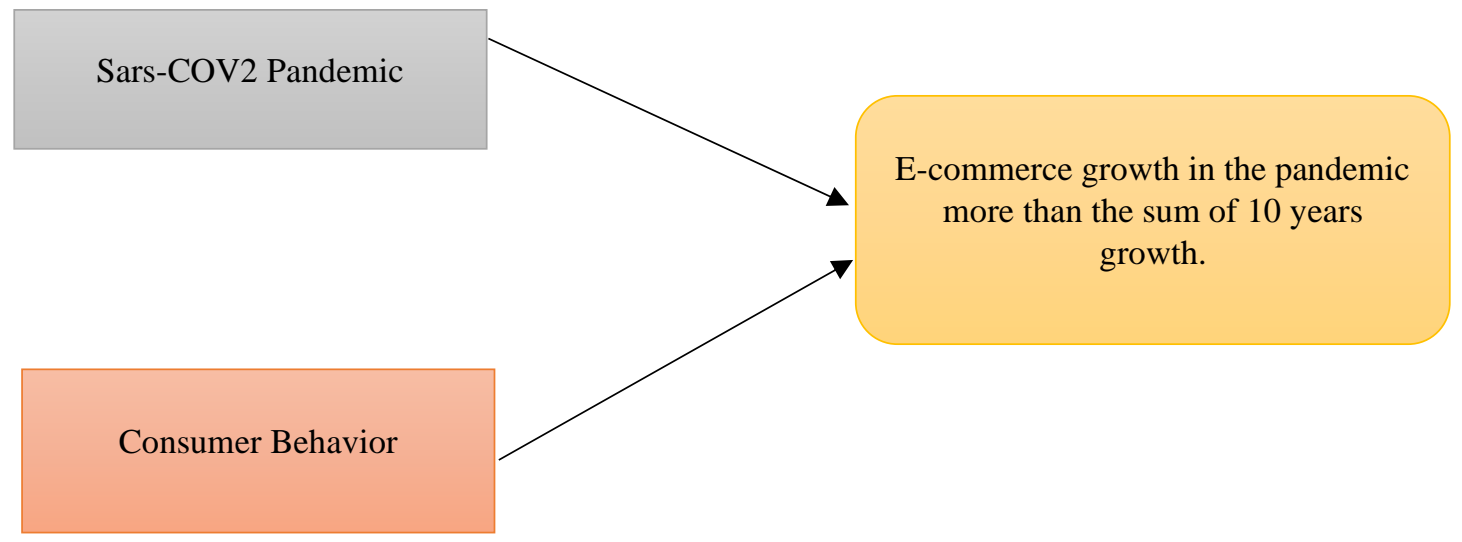

Figure 2: Dependent and independent Variables of Hypothesis

\subsubsection{Covid-19}

Coronavirus is considered to be one of the most infectious diseases, which appears mainly with rigorous acute respiratory syndrome. The particular disease has evolved as a pandemic public health crisis due to its widespread spread within the United States. The COVID-19 pandemic is accelerating its transition to digital commerce in a very significant way. Consumers are expected to practice social distancing. COVID19 is identified as an independent variable because the economies of countries and the world are significantly affected. Based on this particular pandemic, countries have set a higher level of restrictions for both individuals and businesses. This virus has caused a large number of disasters in the world economy. COVID-19 is presented as an independent variable in this particular study where the entire economy of the entire population relied on this particular pandemic to a greater extent. (Anwar, 2020)

\subsubsection{Consumer Behavior}

Consumer behavior refers to the choice, purchase and consumption of goods and services to satisfy their desires. There are various processes involved in consumer behavior. Initially the consumer tries to find what goods he would like to consume, then he chooses only those goods that promise the greatest benefit. After selecting the goods, the consumer makes an estimate of the money available that he can spend. Finally, the consumer analyzes the prevailing prices of the goods and makes the decision about the goods he should consume. In other words, every consumer today judges the value of a brand and chooses the service only after being satisfied with the quality of the product, the additional service and the elements of trust. (Pohl, 2020). There are various other factors that affect consumer purchases such as cultural, social, personal and psychological. The explanation of these factors is given below (Shah, 2010).

1. Cultural factors: Consumer behavior is profoundly influenced by cultural factors such as: buyer culture, subculture and social class.

2. Social factors: They influence consumer shopping behavior. Important social factors are reference groups, family, role and status.

3. Personal factors: They influence consumer behavior. Some of the important personal factors that influence buying behavior are: lifestyle, economic situation, profession, age, personality and self-concept. These factors became important elements in the study of consumer behavior in shifting purchases towards e-commerce in the food and household sector (June, 2020).

4. Psychological factors. There are four important psychological factors that influence consumer buyer behavior. These are: perception, motivation, learning, beliefs and attitudes (Shah, 2010)

Many people at different times are influenced by savage or soft politics and international relations. A concrete case is that of Chinese products imported to the US, which during the pandemic period had a decline of $38 \%$. (June, 2020) 


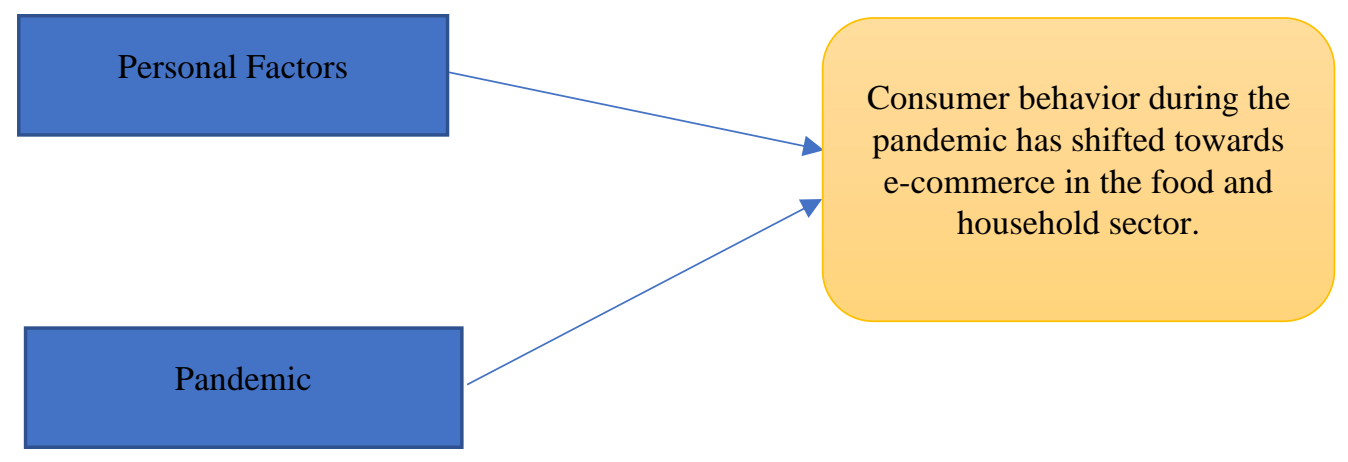

Figure 3: Factors of the second hypothesis

\subsection{E-commerce trend in product types}

In reality, e-commerce sales are not on an upward trend across all of its sectors, although some industries are seeing high levels of growth. This is especially true for online retailers of hygiene products, groceries and household items. Shopify.Inc, the largest software in Canada, has grown over $135 \%$. During this period, he stated that he has seen the opening of numerous online stores for food products and household items that were associated with additional hygiene products. A study done by Engine found that people are spending on average $10-30 \%$ more money and time online. Online food trade grew in the second week of March as shoppers turned online to find goods they needed that were not available at their local grocery stores. The chart below (Graph 2 ), with data from Intelligence (2020), shows a huge increase in ecommerce related to groceries. The rest of e-commerce seems to have shaken up a bit.

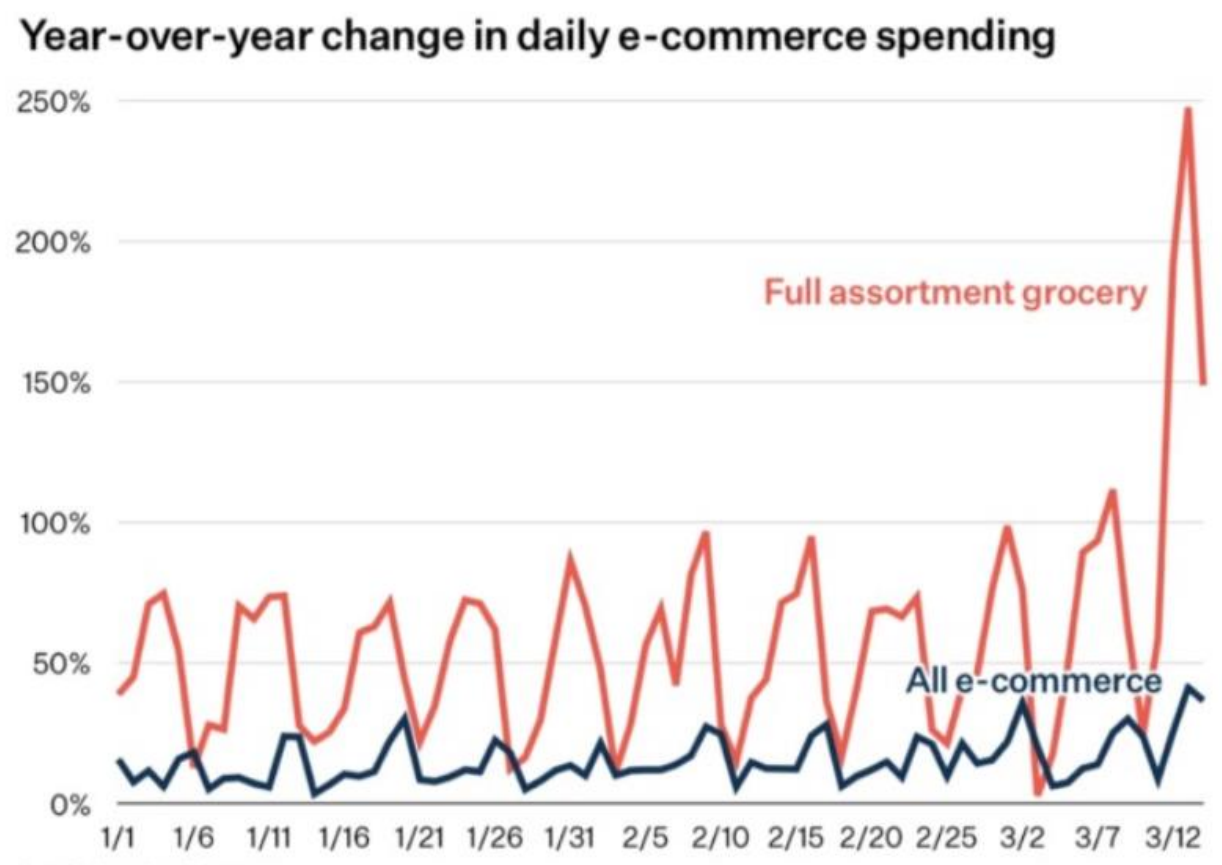

Graph 2: Change of e-commerce per day

As it is seen in Graph 2, food growth has increased by more than $150 \%$ over the period. At the same time, e-commerce has graphically surpassed the growth of 10 years in a period of 3 months. 


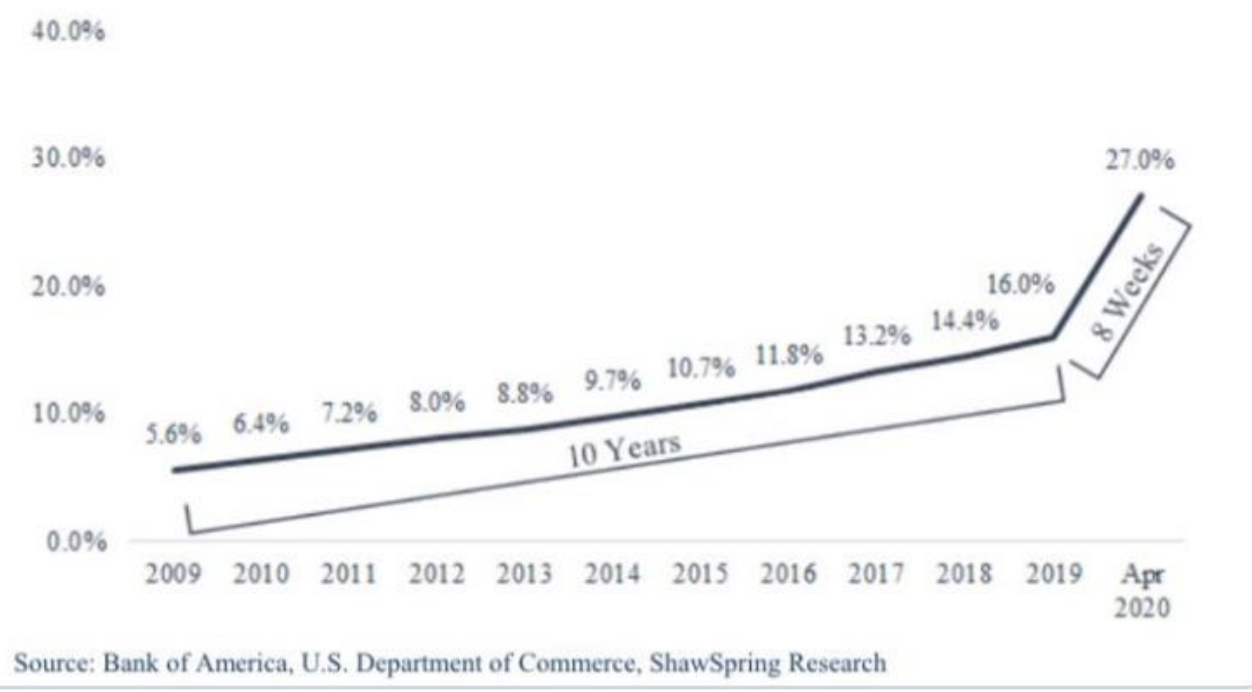

Graph 3: E-commerce change over the years

Graph 3 shows that online commerce has changed consumer behavior and therefore this behavior already penetrates new demand for different products and especially during the pandemic. The big break of the linear graph taken by the online commerce department is explained as the provocation of the economy to enter a trade of technological levels and the disappearance of physical stores, the reduction of the level of use of cash, etc.

The study aimed to identify the direction of consumer behavior during the pandemic and economic isolation in 2020 towards the e-commerce sector. In the study, through empirical analysis it was aimed to analyze the change of consumer behavior during the outbreak of the pandemic; consumers' essential and non-essential products; and the impact of the pandemic on online commerce as the only way for consumer spending during the closure of sectors of the economy. As a consequence, the following research questions were formulated:

1- How much is the consumer behavior affected by the pandemic and the changing economic-political situations?
2- Is the food sector developed more via the e-commerce during the pandemic?

3- Has the pandemic and sectarianism affected economic hours in online trading? If so, what is this difference?

\section{Method of the study}

\subsection{Research design}

In the study, quantitative method was adopted. The details about the study are given below.

\subsection{Participants}

In the study, there were a total of 350 participants between the ages of 16-50 who were selected randomly on voluntary basis. The demographic information about the participants is given in Table 1 below.

\begin{tabular}{|l|l|l|l|}
\hline Age & Male & Female & Total \\
\hline $16-20$ & 19 & 25 & 44 \\
\hline $21-30$ & 30 & 38 & 68 \\
\hline $31-40$ & 50 & 95 & 145 \\
\hline $41-50$ & 30 & 40 & 70 \\
\hline Up to 50 & 10 & 13 & 23 \\
\hline Total & 139 & 211 & 350 \\
\hline
\end{tabular}

Table 1: Demographic information about the participants

\subsection{Data collection and analysis of the data}

In the data collection process, firstly, surveys were conducted through a structured questionnaire tested for reliability at the University of Mumbai center. The questionnaire was distributed electronically using randomly sampling method. There were a total of 350 respondents. Linear regression analysis, collection, processing and interpretation of data. Specifically, there are three issues in which they will serve as tools to conduct data regression analysis. Two main sources of information were as in the following: a) Primary Sources: Data collected from the University of Mumbai study. Data published by Yahoo financial on the continuous growth of online commerce, reports and interpretive graphs of Google Trends that explain all the movements in the sectors involved in online commerce.

b) Secondary Resources: Utilizing studies and literature reports on consumer behavior during the pandemic and online commerce performance from statements by Shopify, Business Magazine, New York Times. The complete e-commerce book by Janice Reynolds, Taylor and James reports published on Google during the pandemic period. 


\section{GENERAL MANAGEMENT}

Study population and sampling.

For the first and second research questions (How much is the consumer behavior affected by the pandemic and the changing economic-political situations?/ Is the food sector developed more via the e-commerce during the pandemic?), the randomly selected 350 participating respondents between the ages of 16-50 were taken in the study, while for the third research question (Has the pandemic and sectarianism affected economic hours in online trading? If so, what is this difference?), a 51-day observation of online trading were taken in the study.

The questionnaire was sent to the participants electronically and their collection and disposal on the board was conducted electronically via Google Trends. They are divided into 5 age group segments as given in Tables 2 and 3 below:

\begin{tabular}{|l|l|l|l|}
\hline Age & Purchasing decision making & Respondents & $\%$ \\
\hline $16-20$ & Online Shopping & 104 & 29.71 \\
\hline $21-30$ & Cel shopping & 81 & 23.14 \\
\hline $31-40$ & Physical stores & 48 & 13.71 \\
\hline $41-50$ & Markets in the country & 60 & 17.14 \\
\hline Up to 50 & Big Bazaar & 57 & 16.28 \\
\hline Total & Total & 350 & 100 \\
\hline
\end{tabular}

Table 2: Participants' consumer behavior

\section{Results}

The results of the study are illustrated and presented as in the following.

\subsection{Results based on the observations and the related literature}

\begin{tabular}{|c|c|c|c|c|c|c|c|}
\hline \multicolumn{8}{|c|}{ Observation Table } \\
\hline & hange in consum & buying habi & & & & & \\
\hline \multicolumn{2}{|c|}{ Group of Ages } & \multirow{2}{*}{$\begin{array}{l}\text { Online } \\
\text { Shopping } \\
20\end{array}$} & \multirow{2}{*}{$\begin{array}{l}\begin{array}{l}\text { Cel } \\
\text { shopping }\end{array} \\
28 \\
\end{array}$} & \multirow{2}{*}{$\begin{array}{l}\text { Physical Stores } \\
10\end{array}$} & \multirow{2}{*}{$\begin{array}{l}\text { Stores in the } \\
\text { country } \\
10\end{array}$} & \multirow{2}{*}{$\begin{array}{l}\begin{array}{l}\text { Online retail } \\
\text { store }\end{array} \\
13\end{array}$} & \multirow{2}{*}{$\begin{array}{l}\text { Total } \\
80\end{array}$} \\
\hline $16-20$ & Observed value & & & & & & \\
\hline & Expected value & 23.77 & 18.51 & 10.97 & 13.71 & 13.02 & 80 \\
\hline \multirow[t]{2}{*}{$21-30$} & Observed value & 40 & 31 & 20 & 15 & 14 & 120 \\
\hline & Expected value & 35.65 & 27.77 & 16.457 & 20.571 & 19.542 & 120 \\
\hline \multirow[t]{2}{*}{$31-40$} & Observed value & 20 & 15 & 5 & 20 & 22 & 75 \\
\hline & Expected value & 22.28 & 17.35 & 10.28 & 12.857 & 12.214 & 75 \\
\hline \multirow[t]{2}{*}{$41-50$} & Observed value & 9 & 7 & 4 & 5 & 11 & 38 \\
\hline & Expected value & 11.291 & 8.794 & 5.211 & 6.514 & 6.188 & 38 \\
\hline \multirow[t]{2}{*}{ Up to 50} & Observed value & 9 & 4 & 2 & 10 & 7 & 37 \\
\hline & Expected value & 10.994 & 8.562 & 5.074 & 6.342 & 6.025 & 37 \\
\hline \multirow[t]{2}{*}{ Total } & Observed value & 104 & 81 & 48 & 60 & 57 & 350 \\
\hline & Expected value & 104 & 81 & 48 & 60 & 57 & 350 \\
\hline
\end{tabular}

Table 3: Observations performed

According to Table 3, published by UGC CARE JOURNAL it can be seen that there is a correlation on the existence of an association between age group and consumer behavior during the pandemic. The statistical value according to the published study is convincing $(p=0.5)$. 


\section{GENERAL MANAGEMENT}

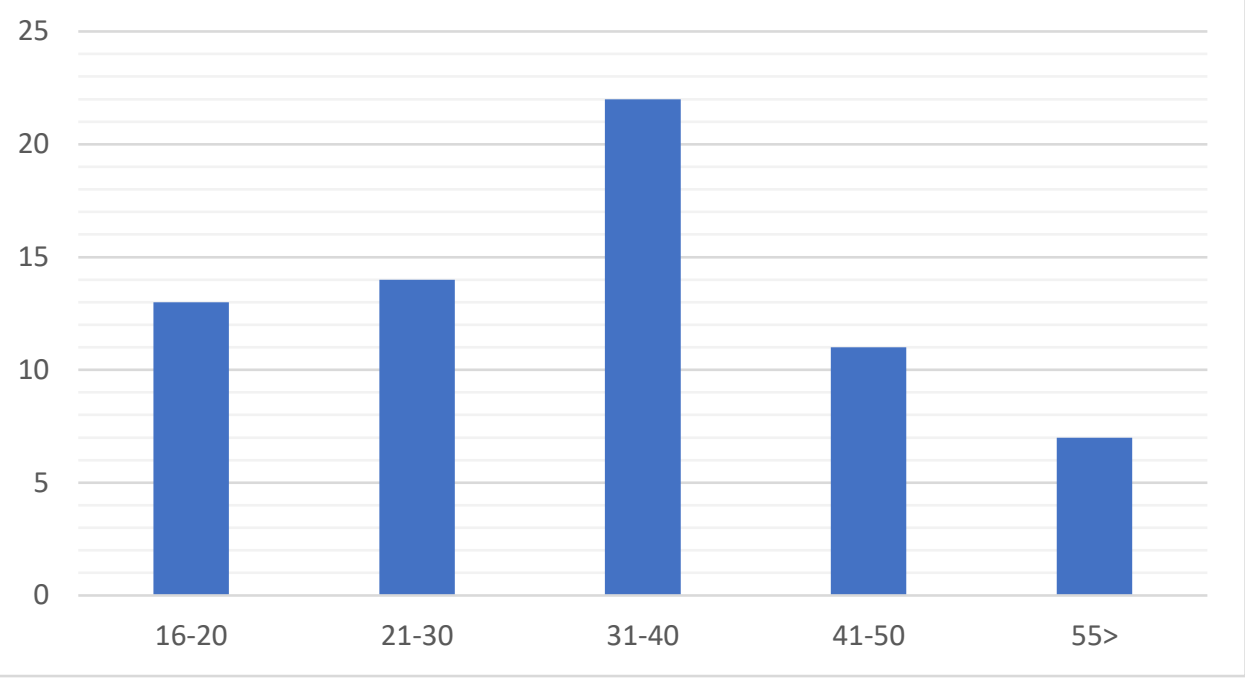

Graph 4: Consumer behavior during the pandemic

The graph no. 4 shows a significant change in the movement of the curve over online commerce. During the pandemic most products are preferred to be bought online and at the same time we notice from the data that in the segment of the age group 41
50 years we have an increase in online trade and the ratio with the segment $16-20$ years is $1 / 2$ and $1 / 3$ with the segment> 50 . From the data of 2019, the last two segments contained only $14 \%$ of purchases in online trade.

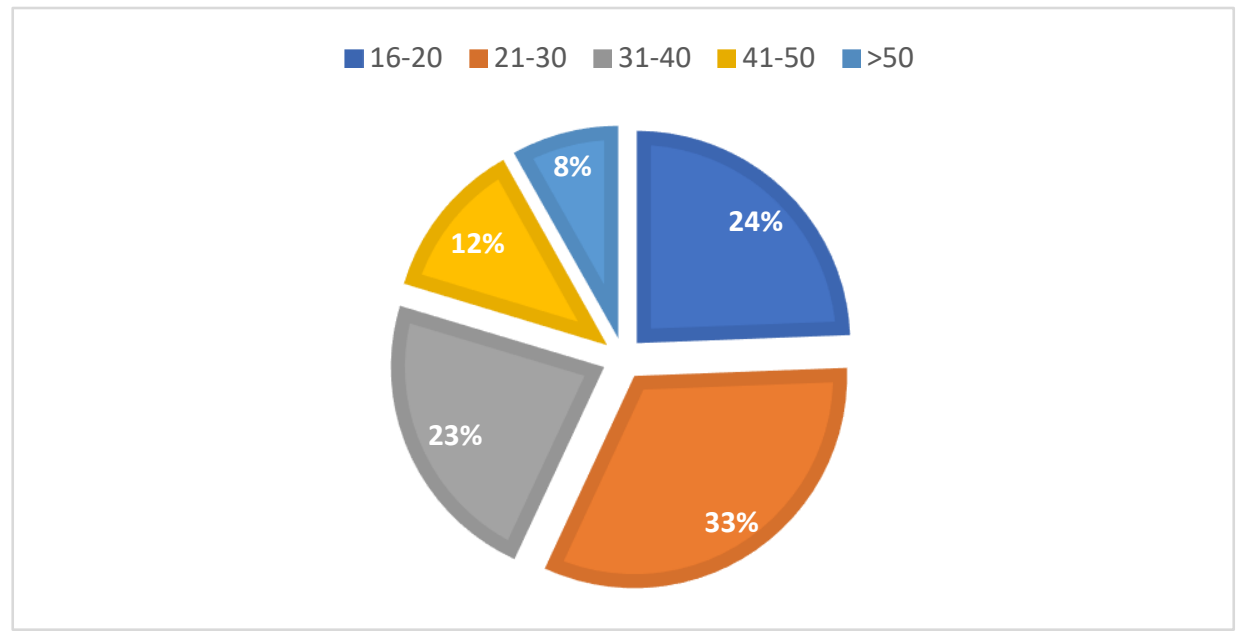

Graph. 5: Online trade in age groups

From the Graph 5 processed only for the online commerce category we notice that the last two segments have increased by over $8 \%$ and we have a contraction of the $Z$ century age group for platform use.

Most people try to avoid physical purchases in the market. During this outburst in the community, people prefer to stay home. About $29.71 \%$ of people prefer to shop online by comparing physical stores in the market. Instead of queuing, most people buy the product they need using online commerce. It was also noticed that people go to the physical store to buy the product. Meanwhile $13.71 \%$ of respondents preferred the physical store compared to online shopping. At the same time in 2019 this figure was over $59 \%$ of people who wanted to make purchases in physical stores.

\begin{tabular}{|l|l|l|l|l|l|l|l|}
\hline \multicolumn{2}{|l|}{ Consumers mostly prefer } \\
\hline \multirow{2}{*}{ Group of Ages } & $\begin{array}{l}\text { Homemade } \\
\text { food }\end{array}$ & $\begin{array}{l}\text { Restaurant } \\
\text { food }\end{array}$ & $\begin{array}{l}\text { Fast } \\
\text { food }\end{array}$ & $\begin{array}{l}\text { Fast } \\
\text { street } \\
\text { food }\end{array}$ & $\begin{array}{l}\text { Custom } \\
\text { food } \\
\text { online }\end{array}$ & Total \\
\hline $16-20$ & Observation Value & 17 & 7 & 7 & 8 & 5 & 44 \\
\hline & Expected value & 16.845 & 2.011 & 1.634 & 1.382 & 22.125 & 44 \\
\hline $21-30$ & Observation Value & 30 & 4 & 2 & 3 & 29 & 68 \\
\hline & Expected value & 26.0342 & 3.108 & 2.525 & 2.137 & 34.194 & 68 \\
\hline $31-40$ & Observation Value & 70 & 4 & 3 & 0 & 68 & 145 \\
\hline & Expected value & 55.514 & 6.628 & 5.3857 & 4.5571 & 72.914 & 145 \\
\hline
\end{tabular}




\section{GENERAL MANAGEMENT}

\begin{tabular}{|l|l|l|l|l|l|l|l|}
\hline \multicolumn{2}{|l|}{ Group of Ages } & $\begin{array}{l}\text { Homemade } \\
\text { food }\end{array}$ & $\begin{array}{l}\text { Restaurant } \\
\text { food }\end{array}$ & $\begin{array}{l}\text { Fast } \\
\text { food }\end{array}$ & $\begin{array}{l}\text { Fast } \\
\text { street } \\
\text { food }\end{array}$ & $\begin{array}{l}\text { Custom } \\
\text { food } \\
\text { online }\end{array}$ & Total \\
\hline $41-50$ & Observation Value & 7 & 0 & 0 & 0 & 63 & 70 \\
\hline & Expected value & 26.8 & 3.2 & 2.6 & 2.2 & 35.2 & 70 \\
\hline Up to 50 & Observation Value & 4 & 0 & 0 & 0 & 19 & 23 \\
\hline & Expected value & 8.0805 & 10.25 & 0.854 & 0.7228 & 11.565 & 23 \\
\hline Total & Observation Value & 134 & 16 & 13 & 11 & 176 & 350 \\
\hline & Expected value & 134 & 16 & 13 & 11 & 176 & 350 \\
\hline
\end{tabular}

Table 4: Observations 2

From the data of Table 4, it is confirmed that there is no relationship between age and the situation that the pandemic has caused for the continuity of consumer behavior for food products.

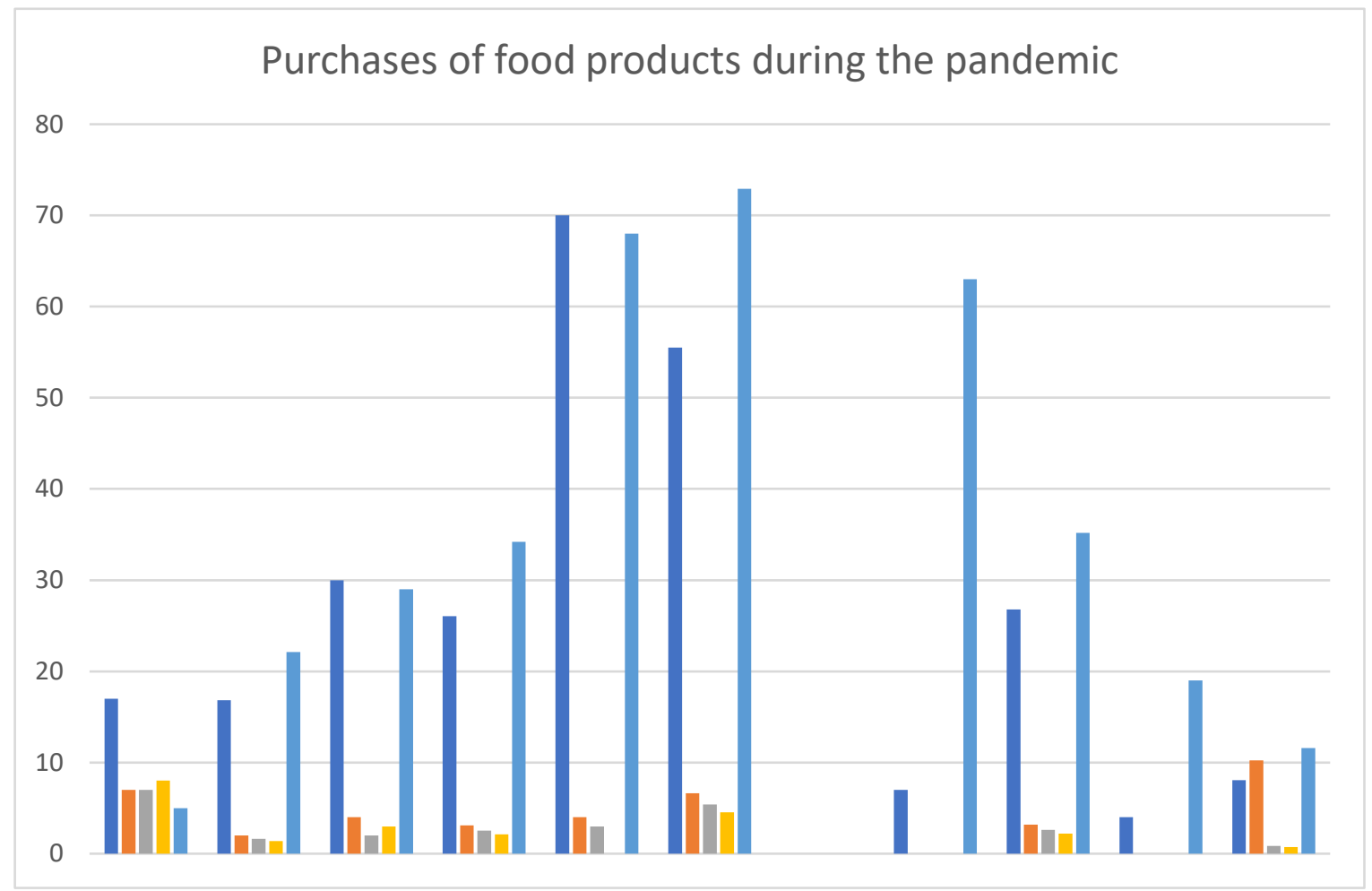

Graph 6: Trend of movement in food purchases during the pandemic

The Graph 6 shows the trend of movement over food purchases during the pandemic period. From this graph we see that the segment of the age group between 16-20 years old exposes for us surprises and a step towards the review on the theoretical elements of consumer behavior. Of course, during the pandemic, online custom food has grown and replaced the closing space of restaurants, supermarkets, etc. Many restaurants in the first week of March turned to the network of the company Shopify, Amazon, etc. for the opening of online stores and restaurants where through the application and websites you can order different foods and products easily by avoiding waiting for the order, time to go to the restaurant or physical store, facing many people in an isolated and enclosed space, and many other issues that are replaced by e-commerce.

To create a clearer picture based on the data of the above study I managed to obtain semi-processed data from Google Trends and Yahoo Financial by regrouping them, and throwing them in support of the above hypotheses.

From the main observations of international platforms on data processing and collection was observed a very large increase in online food purchases. According to Google Trends the categories of growth in the highest percentage in the pandemic period were as follows:

\begin{tabular}{|l|l|}
\hline & Growth \\
\hline Dietic food & $485 \%$ \\
\hline Auxiliary foods & $305 \%$ \\
\hline Homemade food & $225 \%$ \\
\hline
\end{tabular}

Table 5: Growth of categories at the time of pandemic

From the data and the reports extracted from the Google platform walk simultaneously to the conclusions regardless of the age group variable. So during the time of the pandemic the biggest expenses from online consumers went to food 


\section{GENERAL MANAGEMENT}

purchases. This conclusion runs parallel to the main study as we note that diet foods have the largest increase and has brought a huge boost to the use of e-commerce platforms.

To make clearer all the supporting elements to validate the hypotheses through data published by Yahoo financial and
Google trends I will compare several categories. The comparison will be through the e-commerce sector, the company with the highest growth during the pandemic that is Shopify.inc and the purchases of food products by consumers.

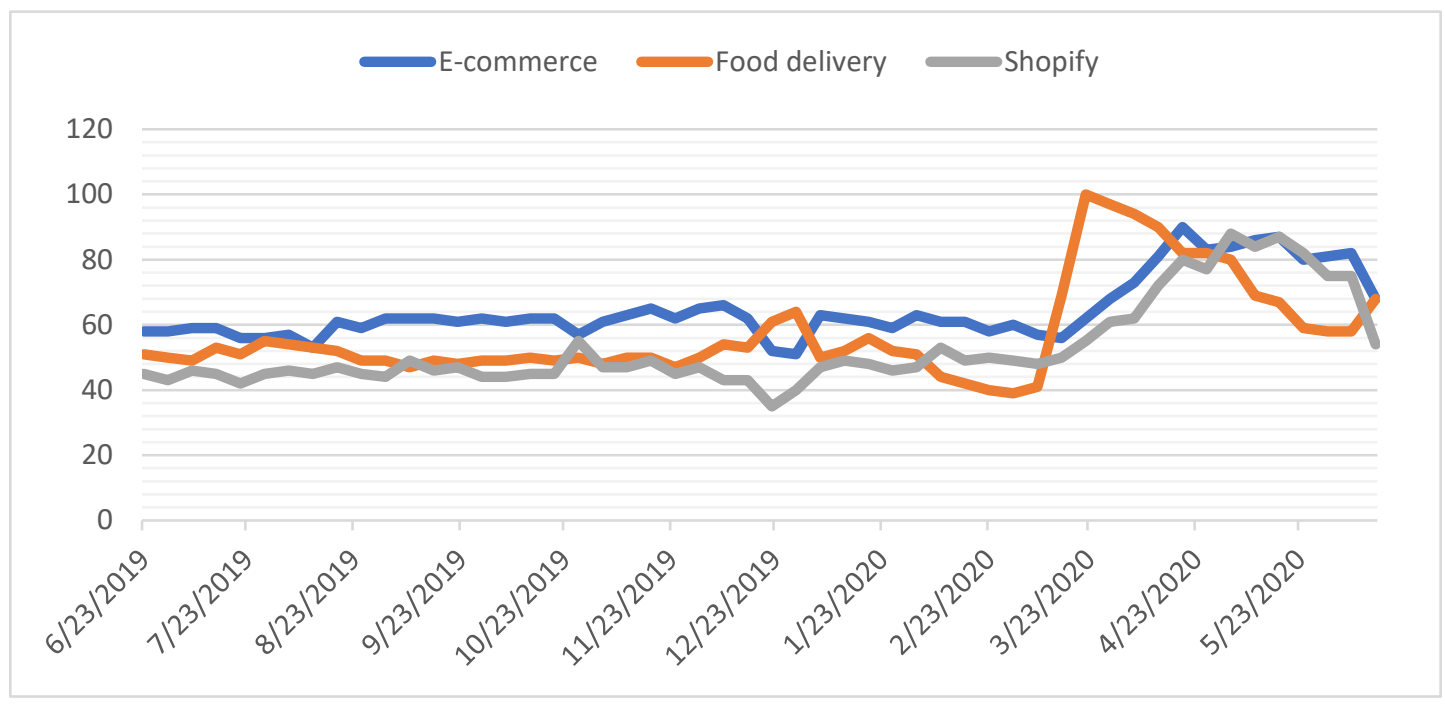

Graph 7: Comparison of companies

Through the data obtained and regrouped in excel concludes Graph 7 where it shows us enough to support the second hypothesis that: The economic situation during the pandemic and consumer behavior have turned online trade into the most developed activity and the food sector has catapulted this growing.
Based on the data from magazines such as New York times, Economics, etc., showed an increase in the levels of online stores. Shopify.inc is the company with the highest growth during the pandemic of opening stores and new customers. This is of course protected by data published by Yahoo financial:

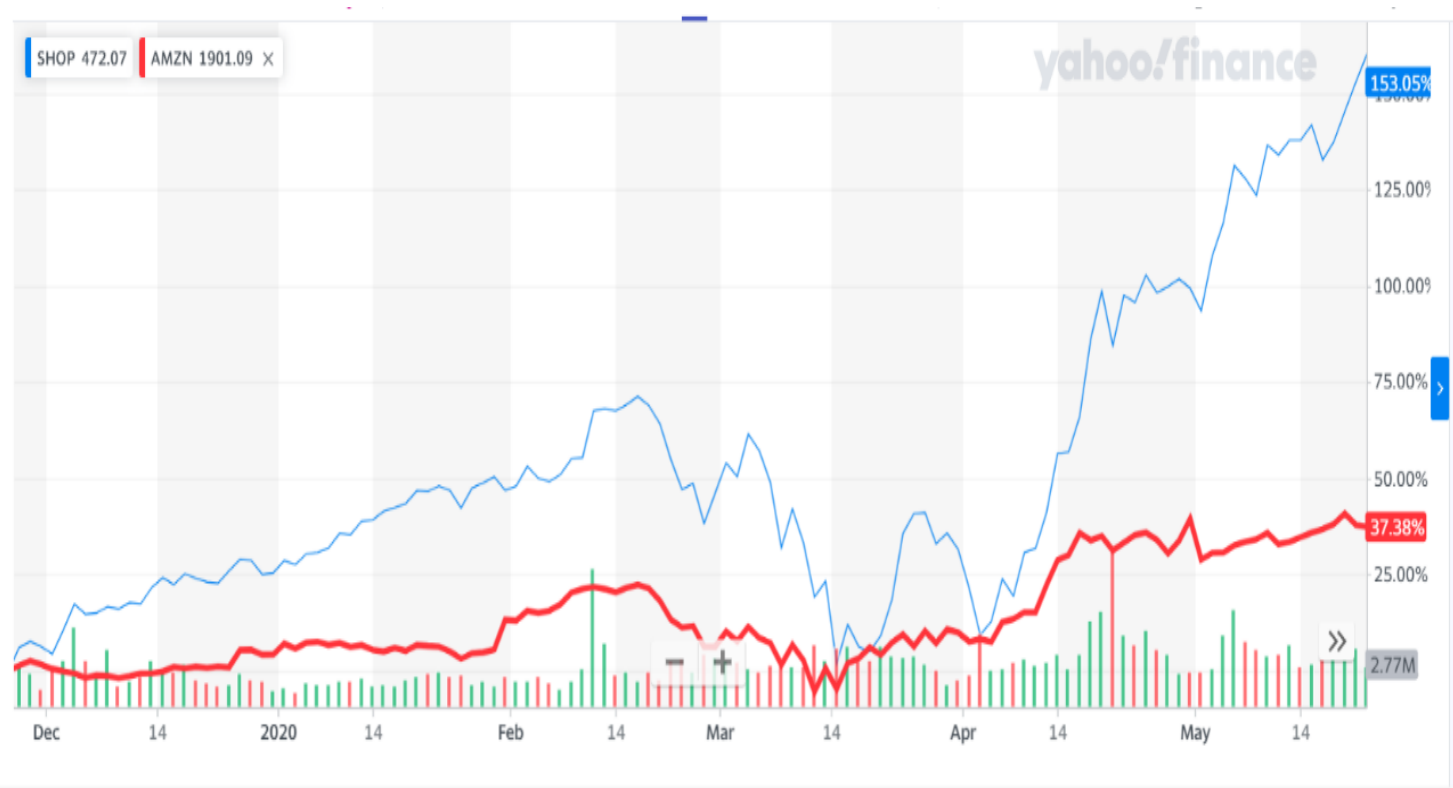

Graph 8: Evaluation of two companies

From the Graph 8, the rating of the two most powerful companies in America are seen. From the published data we conclude that the company Shopify has developed in its $153.05 \%$ against the company Amazon with $37.38 \%$ during the pandemic. 


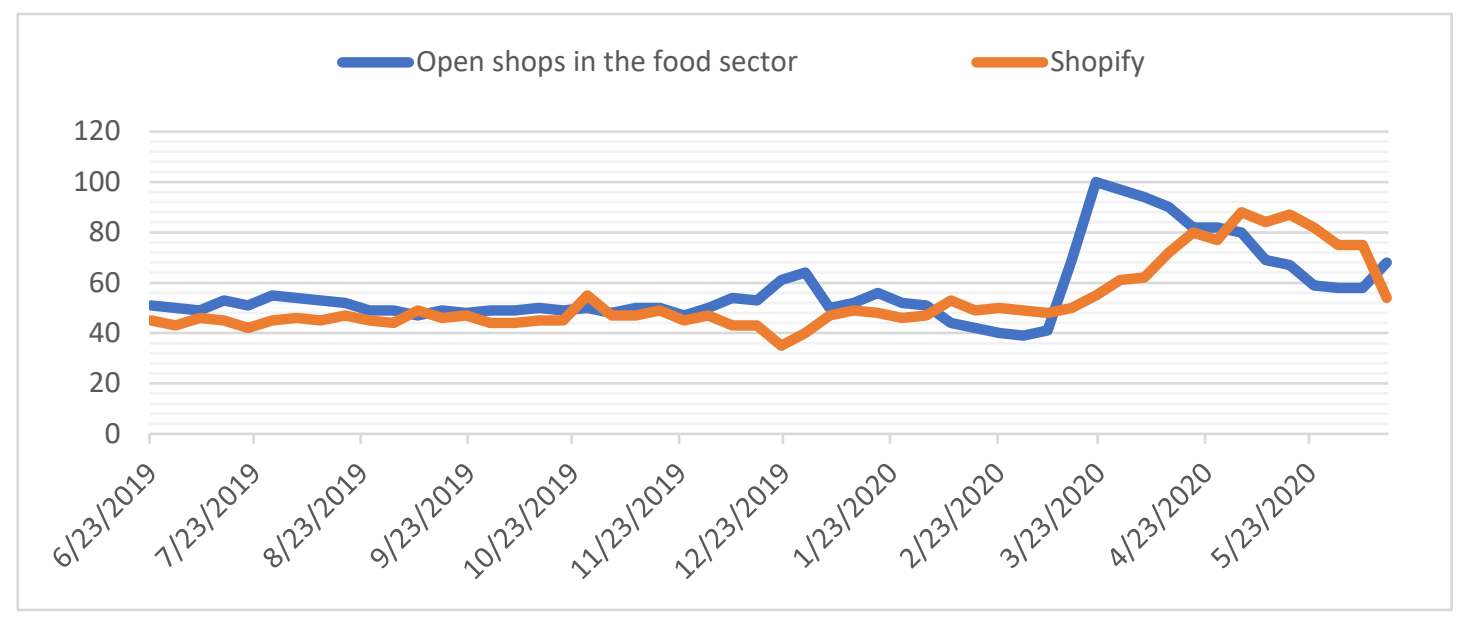

Graph 9: Online food products and Shopify

According to the Graph 9, it can be seen that in the period between the end of February and the end of April the growth of open shops in the food sector exceeds the growth of online trade by surpassing the graph 50 points more within a period of 14 days. According to the statement of the company Shopify, the increase in this form has given the company revenues of 120 million dollars or in relation to $2019,78.7 \%$ more.

In addition, it can be seen that from February 23 to May 23, there is a link between the economic situation and the pandemic situation and consumer behavior that lead to the growth of online commerce. At the same time, changing consumer behavior has led to an increase in the food sector in online trading platforms. As a result, the pandemic has affected businesses by putting them in a difficult position for a short period of time and at the same time consumer behavior has changed by adding new elements characteristic of purchases as well as the household incomes and all expenditures of food products.

\subsection{Results based on the empirical data analysis}

An important piece of information that emerged as a result of the descriptive analysis is the change in consumer behavior based on the defined age groups. The time in which this behavior has changed was the difficult period of pandemic and economic stagnation. Statistical information on the relationship between age group and consumer behavior during the pandemic and at the same time the relationship between age group and behavior change for food products is important to complete the analysis.

\subsubsection{Factor analysis}

Factor analysis is the first type of analysis through which it is possible to identify the variables that explain the change in consumer behavior during the pandemic in e-commerce. This test serves as the first filter for selecting variables from a very high number of them to a more reduced number of variables. Initially the variables that were considered are:

Dependent variable: E-commerce growth, altered consumer behavior

Independent variable: Covid19 respiratory disease, Consumer behavior, Age group,

Only variables with an explanatory capacity higher than $60 \%$ are considered. Meanwhile, as mentioned above the dependent variable is dependent on the independent variables.

\subsubsection{Linear regression analysis}

The basic equation of a linear regression model is:

$y=\beta 0+\beta 1 x+\varepsilon$

Reliability coefficient $=95 \%$

To construct the linear regression equation, two important tests were administered. After entering the data in excel the conclusions of the regression analysis are as follows:

\begin{tabular}{|l|l|}
\hline Multiple R & 0.639908258 \\
\hline R Square & 0.679482579 \\
\hline Adjusted R Square & 0.325122947 \\
\hline Standard Error & 5.148560081 \\
\hline
\end{tabular}

Table 6: Elements of description of Regression analysis

Multiple R. is the Correlation coefficient that measures the strength of a linear relationship between two variables. The correlation coefficient can be any value between -1 and 1 , and its absolute value indicates the strength of the relationship. The higher the absolute value, the stronger the relationship:

1 means a strong positive relationship
1 means a strong negative relationship

0 means no relationship at all.

In this case the calculations shows R2 $=67.9 \%$ so the model of the selected variables is representative and explains the dependent variable.

Fisher Test- From ANOVA we have: 


\begin{tabular}{|l|l|l|l|l|l|}
\hline ANOVA & & & & & \\
\hline & Df & SS & MS & F & Significance F \\
\hline Regression & 1 & 128.6685 & 128.6685 & 4.254011 & 0.034532 \\
\hline Residual & 7 & 185.5537 & 26.50767 & & \\
\hline Total & 8 & 314.2222 & & & \\
\hline
\end{tabular}

The value of Significance $F$ indicates the reliability of our hypothesis laid out in the previous chapter. The data in the table show a result of 0.034 which is also less than 0.05 . So there is a link between age group and consumer behavior for e- commerce purchases. This is certainly confirmed by other sociocultural factors, the development of technology, the willingness of young age groups to buy more during the pandemic, etc.

\begin{tabular}{|l|l|l|l|l|}
\hline & Coefficients & Standard Error & t Stat & P-value \\
\hline Intercept & 11.9756617 & 5.031316 & 4.367776 & 0.003283 \\
\hline X Variable 1 & 0.296775175 & 0.134703 & -2.20318 & 0.049432 \\
\hline
\end{tabular}

From these data it is seen that the value of $P$ is less than 0.05 . From the completed data a regression equation can be constructed.

For this data set where $y$ is the number of people who have used e-commerce during the pandemic and $\mathrm{x}$ is the age taken in the study, so the age group.

$Y=0.29 * 35.11+11.97=22.1519$

With an average age of 35 the use of e-commerce would be around 22 uses and purchases.
So this case studies the change of consumer behavior during the e-commerce pandemic in the food sector. Also in this case the linear regression analysis studies 2 important variables such as: selected age groups and the development of ecommerce in the food purchasing sector.

To construct the linear regression equation, two important tests are tried. After entering the data in excel the conclusions of the regression analysis are as follows:

\begin{tabular}{|l|l|}
\hline Regression Statistics & Results \\
\hline Multiple R & 0.7471944 \\
\hline R Square & 0.8883245 \\
\hline Adjusted R Square & 0.2256349 \\
\hline Standard Error & 7.7970229 \\
\hline
\end{tabular}

Table 7: Elements of description of Regression analysis

From the table it is seen that Multiple $R$ is 0.747 so inside the interval $-1 ; 1$. In this example R2 is 0.888 otherwise $88.8 \%$ : so it is a very convincing and promising result for the variables.
Another test to evaluate our hypothesis is the Fisher Test. From the ANOVA following data are obtained:

\begin{tabular}{|l|l|l|l|l|l|}
\hline ANOVA & & & & & \\
\hline & Df & SS & MS & F & Significance F \\
\hline Regression & 1 & 147.5373 & 147.5373 & 0.775052 & 0.074329 \\
\hline Residual & 8 & 1522.863 & 190.3578 & & \\
\hline Total & 9 & 1670.4 & & & \\
\hline
\end{tabular}

From the ANOVA table it is noted that the value of Significance $F$ is greater than 0.05 and there is no relationship between age and the situation that the pandemic has caused for the continued behavior of consumers for food products.

This means that the period of the pandemic greatly influenced by the economic panic situation (Butterfly effect) and the political situation, the socio-economic closure has caused different age groups to change their consumer behavior towards online food shopping. From the data obtained it is noticed that young age groups from consumers who buy fast food products have turned into consumers of foods with minerals, nutrients, foods rich in vitamins and foods that associated with hygienic safety.

\begin{tabular}{|l|l|l|l|l|}
\hline & Coefficients & Standard Error & t Stat & P-value \\
\hline Intercept & 7.2018448 & 13.44729 & 0.535561 & 0.066826 \\
\hline X Variable 1 & 0.3163321 & 0.359317 & 0.880371 & 0.064329 \\
\hline
\end{tabular}

The data in the table above shows that the value of $P$ is greater than 0.05 .

For the data set where $y$ is the number of people who have used online food ordering platforms during the pandemic and $x$ is the age taken in the study, i.e. age group.

The most useful component in this section is Coefficients. This allows the researchers to construct a linear regression equation in Excel:

$$
\begin{aligned}
& y=b x+a \\
& y=0.3163321 * x+7.2018448 \\
& y=0.316^{*} 35.4+7.20
\end{aligned}
$$$$
y=18.3
$$

At an average age of 35.4 there are 18.3 online food purchases on Shopify.Inc for 176 people surveyed. 
Covid19 data and online commerce during the pandemic were obtained. The latter is studied through a concrete case of the company Shopify.Inc. The growth of the Shopify company during the pandemic has been at high rates where it reached its development at over $153 \%$ of its value compared to 2019 . From the data obtained for 51 days observations on the performance of Covid19 in infections and the performance of e -commerce in food purchases we derive this data from two important tests:

\begin{tabular}{|l|l|}
\hline Regression Statistics & Values \\
\hline Multiple R & 0.949702 \\
\hline R Square & 0.8471591 \\
\hline Adjusted R Square & 0.6379174 \\
\hline Standard Error & 36.825599 \\
\hline Observations & 51 \\
\hline
\end{tabular}

Table 8: Elements of description of Regression analysis

From the observed data we see that $\mathrm{R} 2$ is strongly reliable with the value 0.847 or in percentage: $84.7 \%$. So the model of the selected variables is representative and explains the dependent variable.

Fisher Test: From the data of the Anova table we have:

\begin{tabular}{|l|l|l|l|l|l|}
\hline ANOVA & & & & & \\
\hline & Df & SS & MS & F & Significance F \\
\hline Regression & 1 & 446333.6 & 44.64663 & 2.205773 & 0.0021847 \\
\hline Residual & 49 & 369395.5 & 75.68456 & & \\
\hline Total & 50 & 815729.2 & & & \\
\hline
\end{tabular}

From the data in the table of ANOVA, it is seen that the SarsCov2 pandemic has impacted online commerce by turning it into a high-profit sector and one of the only ways to shop during the pandemic. As Covid19 infection rates increased in percentage as well and e-commerce grew to very high levels, so there is a positive correlation.

\begin{tabular}{|l|l|l|l|l|}
\hline & Coefficients & Standard Error & t Stat & P-value \\
\hline Intercept & 353.19917 & 22.99912 & 15.35707 & 0.001936 \\
\hline X Variable 1 & 0.0001431 & 1.842763 & 7.694529 & 0.05003 \\
\hline
\end{tabular}

The table above shows again that the value of $P$ is significantly less than 0.05 , thus reinforcing the conclusion.

From the completed data we can construct a regression equation

For the data set where $y$ is the change in e-commerce value during the pandemic and $\mathrm{x}$ is the constant change and increase in Covid-19 infections.

The most useful component in this section is Coefficients. This allows the researchers to construct a linear regression equation in Excel:

$y=b x+a$

$y=0.0001431 * 1050077+353.19$

$y=503.26$

For every increase of infections in the values of over 1 million affected, the online trade is positioned at the value of 503.26 of its increase. In other words, for every change in 1 million infections we have a 503.26 increase in the e-commerce sector without considering any other factor. This means that an increase in over 1 million infections leads to about 5 times larger expansion of e-commerce companies and about 5 times more purchases for every 1 million infections.

\section{Discussion and Conclusions}

Discussions about changing consumer behavior driven by online commerce has opened up great discussions and therefore many studies have been done, exceeding expectations from the time effect. In just a few months, hundreds of studies have been published on this phenomenon that occurred in 2020. Certainly this is not the first study in Albania on the relocation of consumers in online commerce, but I believe it is one of the few that undertakes to analyze two phenomena simultaneously such as consumer behavior and online commerce in a not at all normal period both socially and economically.

In addition to providing an overview the study aims to provide more developed information that can be helpful to many companies wanting to open a domain to sell online. Their marketing and running of their store is done based on studies conducted. Directed marketing can be extended to certain age groups that have brought more development, purchases in the analyzed period. Companies can take as a basic information and the results of the above hypotheses on the direction of consumer behavior towards nutrition or hand-made food products.

This paper suggests that during this period that is expected to continue for an even longer time, all companies should consider switching to online business. This requires choosing a domain such as Shopify, which offers the financial and technical convenience of setting up an online store. After this step you certainly need the decision to sell the products and study the market and the consumer.

The first case worth discussing has to do with how consumer behavior changed and had interesting movements during the virus pandemic and economic shutdown. Recall here that, the division created in the age group gave us a clearer picture on the situation and direction of consumer behavior. From the results we can say that with an average age group of 35 years the purchases in online trade are 22 purchases / per day. This goes hand in hand with the study findings taken as reference. Expected results were at the level of 15 purchases / day. So the use of online commerce has been much higher. There are several factors that have influenced this behavior as the 
economic closure was accompanied by the closure of physical stores, the term shopping mall was replaced by online product search.

The conclusions of the analysis show that there is no significant relationship between age group and consumer behavior directed at food products. It was expected from the study (expected value) to have a relationship between the age group as from the theories of consumer behavior and observations of recent years the age of generation $Z$, ie the second millennium to have a higher use of platforms. From consumer behavior we have the premise that young people, adolescents, have such behavior to buy products that are influenced by colors, low nutritional values, efficiency in the use of platforms, socially influenced purchases and socio-cultural effects. However, this from the observations has led to the opposite. In America before the pandemic of the virus the use of Fast Foods has been high from a young age. During the pandemic, people between the ages of 16 and 20 and 20-30 turned to hand-made home-made foods and ordered a small number of online foods, as well as nutritious foods rich in vitamins, proteins. and healthy for the body). So from the hypothesis we notice an oblique movement of age groups where the highest use of online commerce for e-commerce is between the ages of $30-50$ years. This occupies more than $38 \%$ of the mass. So from the conclusions drawn in the study contradicts the studies considered for basic literature. One reason for this discrepancy is the pandemic, which we are seeing breaking some consumer behavior laws and economic laws.

We can also see that there is a link between the pandemic and economic closure and also with the key variable such as the change in online commerce. There was a correlation between the variables and the main hypothesis did not fall. The findings were in line with the graphs developed by Yahoo Financial and Google trends. Of course, this large movement of consumers towards online commerce was influenced by other factors that could be expressed in variables, but their strength was below $50 \%$. Some of them were panic created by store closures, low product prices, mass theory, and so on. So it is noticed that online commerce turned for 3 consecutive months into spending only the revenue of global consumers.

The main results of the study show that the changed consumer behavior is already oriented towards online commerce where it remains the only source of spending during the closure of the private and state economic sectors. Again, consumer behavior tells us that companies should already be marketing products based on all ages as the study conducted clearly shows that there is no strong link between age group and online shopping of food products. The claim that online commerce took place during the pandemic was later substantiated, where for a ratio of 1 million infected, the value of e-commerce companies for food products increased over 500 times.

So, below there are summarized all the findings that are compared with the citations in the text body:
1- From the analysis performed based on the facts and variables determined on the effect of importance in the study, it is understood that the pandemic changed consumer behavior by applying one of the laws of consumer behavior which is: the peak of short-term consumer demand influenced by external effects. So, Covid- 19 pandemic validates and does not create paradigms in the laws of consumer behavior.

2- Consumer orientation towards online shopping. As the only window in the economy to have a stable level of spending and not to carry out a review until the economic depression. The impact of online platforms had two effects: saving expense reports over the 3 months; galloping growth in international and national markets creating a silent war between companies of this profile.

3- Orientation of consumers towards controlled basic products. This is the effect created by the pandemic. In different age groups before the pandemic, the online ordering of food was different from the level of use to the type of product. The pandemic influenced the unification of these two changes. Every age group has an increased and constant use of online platforms for ordering basic products and what unites them is the association with disinfectant and very healthy products.

4- There was a great development in conglomerates such as shopify, amazon, etc. for research and interest in online platforms, for the opening of new economic units by people (shopify.inc). Making the online supply large and justifying the peak demand for products.

\section{References}

[1] Chen, Ch. (2003). An investigation of significant factors affecting e-commerce, pp. 41-43.

[2] Crushman \& Wakefield. (2020). Warehouse market during the pandemic. Coronavirus impact on e-commerce.

[3] Craven, M., \& Liu, L. (2020). COVID-19: Implications for business.

[4] Eventbride. (2020). Creative Business Planning in a Crisis.

[5] Hillier, L., \& Gilliland, N. (2020). Stats roundup: Coronavirus impact on marketing, ecommerce \& advertising.

[6] Markey, B. (2020). The Economics of Artificial Intelligence.

[7] Meyer, S. (2020). Understanding the COVID-19 Effect on Online Shopping Behavior.

[8] MoEngage. (2020). COVID-19 Regular Responses, Marketing Strategies.

[9] N.Y. Times. (2020). Coronavirus Spurs a Wave of Suspect Websites Looking to Cash In.

[10] Pymnts. (2020). Can e-Commerce overcome COVID-19?

[11] Shaikh, A. (2020). Effective Factors in Changing the Buying Behavior of Consumer Due to Covid-19.

[12] Shopify Inc. (2020). Financial reports.

[13] Unctad. (2020). Global Trade Impact of Coronavirus (COVID19) Epidemic. 